\title{
Várostervezés és az e-kormányzat kiépítése Dániában
}

White Paper a szervezeti architektúra kiépítéséről. (Részletek.) (Ministry of Science, Technology and Innovation, Denmark: „White Paper on Enterprise Architecture")

Így hivatkozzon erre a cikkre:

Gaugecz Ádám, Rohonyi András. „Várostervezés és az e-kormányzat kiépítése Dániában”.

Információs Társadalom IV, 2. szám (2004): 90-101.

A folyóiratban közölt müvek

a Creative Commons Nevezd meg! - Ne add el! - Így add tovább! 4.0

0

Nemzetközi Licenc feltételeinek megfelelően használhatók. 


\section{Várostervezés és az e-kormányzat kiépítése Dániában}

Az e-kormányzat dán modellje a közszféra teljes egészének modernizációját célozza meg. Ez az intézmények információtechnológiai (IT) eszközökkel való ellátottságának és szervezeti felépítésének együttes, alapos megújításával érhető el. Az ekormányzat kiépülése során a legtöbb problémát - az elektronikus megoldások és az infrastruktúra fejlesztése mellett - elsôsorban a szervezeti egységek felépítése okozza. A dán Tudomány-, Technológia- és Újításügyi Minisztérium által közzétett „White Paper on Enterprise Architecture" címú tanulmány az e-kormányzat kiépítésének és a hagyományos kormányzati tevékenység ezzel együtt járó átalakításának egyik lehetséges megoldásaként a várostervezés - igen hasznosnak tûnő - analógiájára épülố „szervezeti architektúra” modellek használatát javasolja. Az alábbiakban a tanulmány „Elektronikus várostervezés” címú fejezetét kissé rövidítve közöljük.

Cím: White Paper a szervezeti architektúráról

Eredeti cím: White Paper on Enterprise Architecture

Közrebocsátó: Ministry of Science, Technology and Innovation. Dánia, 2003

\section{[...] \\ Elektronikus várostervezés}

Az alábbi fejezet a White Paper által javasolt architektúra-modell alkalmazását a várostervezés metaforájának segítségével mutatja be, rávilágítva, hogy a házakat, utakat és közmûveket magába foglaló komplex városi struktúrákat megtervezô építész hogyan tud segíteni a rendszerezésben és a szervezésben. Az architektúra-modell kulcsa két ciklikus és ismétlődő - folyamat, melyek egymást gazdagítják és befolyásolják. [...]

A White Paper nem ígér gyors megoldásokat, inkább azokra a döntô fontosságú szervezeti, folyamat-irányultságú és múszaki természetû mechanizmusokra tereli a figyelmet, amelyeknek a megvalósítása, menedzselése és értékelése szükséges ahhoz, hogy a szintén megtervezett, menedzselt és a szervezeti architektúrára is figyelmet fordító fejlesztési programok és befektetések valódi haszonnal járjanak.

A White Paper-nek nem az a célja, hogy a döntési folyamatokat egységesítse, monopolizálja vagy újra bürokratizálja. A közszféra intézményei nagymértékben önállóak, beágyazódnak saját kulturális környezetükbe, és múködésüket törvények szabályozzák. Ezért azt hangsúlyozzuk, hogy az architektúra általános elveit, amelyek a hatékonyság és a szervezetek közötti együttmúködés igényében gyökereznek, hogyan lehet a közösség egészének javára úgy megvalósítani helyileg, hogy közben a helyi önkormányzatiság ne sérüljön.

${ }^{1}$ http://www.oio.dk/files/whitepaper.pdf 


\section{Várostervezés és szervezetépítés}

A közszféra IT rendszereinek fejlesztése sok tekintetben hasonlít a várostervezés folyamataira. Nagyvárosaink fejlődése számtalan egyidejúleg futó projekten keresztül valósul meg. Ezek összehangolása bonyolult feladatot jelent. Igy merült fel egy általános tervezési keretrendszer igénye annak érdekében, hogy biztosítva legyen a rendezett fejlődés és koherensebb rendszerek jöhessenek létre.

A szervezeti architektúra kiépítése jól összehasonlítható a várostervezéssel, melynek során közös erôforrások megtervezése történik, amelyeknek a használatára bizonyos szabályok (például biztonsági előírások) vonatkoznak. A várostervezés országos, regionális és helyi szintjeihez hasonlóan a szervezeti architektúra is több szinten fejleszthetố ki:

- országos szinten,

- a gazdasági szektorok vagy a szolgáltatási ágazatok szintjén, és

- az egyedi szervezetek vagy hatósági jogkörủ hivatalok szintjén.

A városi rendezési terv a város fejlesztésének kereteit jelöli ki, meghatározza az ipari és lakóövezeteket, rögzíti a közmúvek biztosításának feltételeit, megtervezi a közlekedési forgalmat. A rendezési terv társadalmi megegyezést fejez ki és elősegíti a város helyi projektumokon keresztül megvalósuló ésszerủ fejlődését, amelyeket a város lakói és vállalatai hajtanak végre.

Egy tervek nélküli város minden pillanatban a káoszt kockáztatja. Tervek hiányában elvész az összhang a vállalkozói befektetések, illetve az út- és közmúfejlesztések között, s a beruházások által mozgásban tartott rendszer múködése bizonytalanná válik. A rendezési terv olyan formális eszköz, amely irányokat és korlátokat jelöl ki, előírja, hogy mi az, ami fejlesztendő, és azt - a döntéshozatalkor mérlegelendő érdekek figyelembe vételével - hogyan lehet megvalósítani. Elkerülhetetlen, hogy az átfogó városrendezési terv elôírásai korlátozzák egyes vállalatok vagy egyének saját terveinek megvalósítását, vagy azokat elviselhetetlenül költségessé teszik. A várostervezés ennélfogva politikai folyamatokon alapszik.

A városok fontos meghatározó vonásaik sajátos adottságaik, például földrajzi helyzetük, demográfiai állapotuk, történelmi hagyományaik, gazdasági struktúrájuk, vagy lakosságuk szakmai-foglalkozási összetétele. Ebből kifolyólag különböző városfejlesztési terveket dolgoznak ki, amelyek a gyakorlatlan szem számára lényegében hasonlónak tûnhetnek, azonban ténylegesen egymástól gyökeresen eltérố „valóságokból" nőnek ki, és szögesen eltérô környezeti viszonyokhoz illeszkednek. Természetesen a várostervezők és az építészek munkája is közös hagyományokra épül, amelyeket a szakmai képzésük és szakmai szervezeteik közvetítenek, a jó tervezôt és építészt azonban elsősorban gyakorlati tudása és tapasztalatai különböztetik meg.

A várostervezési munka mindenekelốtt az adott létesítmény helyére és tervrajzára vonatkozó szabályokat fekteti le, köztük például

- a követendő szabványokat (útszélesség, csővezetékek méretezése, elektromos energiaellátás),

- a megkívánt képesítéseket (a tervezôk és a kivitelezésben résztvevő szakemberek felhatalmazásait), 
- a menedzsmentre vonatkozó előírásokat (szabályokat, értesítési és jóváhagyási kötelezettségeket, engedélyeket).

A várostervezés meghatározza azokat a szabályokat is, amelyek a közüzemi szolgáltatások igénybevételét lehetôvé teszik vagy kötelezốen elő́riják.

[...]

Az információs technológia ugyanígy igényli mind az egyedi rendszerek megtervezésének szabályozását, mind a szolgáltatások másokkal megosztott igénybevételéhez szükséges feltételek kialakítását, ahol célszerű azok közös használata. A kapcsolódási pontok szabványosítása (körültekintôen kialakított interfészek formájában) az IT rendszerek közötti koherencia elérésének is egyik elôfeltétele.

Dániában az infrastruktúra fejlesztése hagyományosan közpénzbőll, a közigazgatás ellenôrzése alatt valósul meg. Az elmúlt években azonban a piaci szereplôk is egyre gyakrabban hajthatnak végre beruházásokat. Az ily módon tehermentesített közszféra koncentráltabban tud foglalkozni a megbízható ellátáshoz és a méltányos piaci feltételekhez szükséges szabályozással.

A várostervezéssel - mint sokdimenziós, soklépcsốs folyamattal - kapcsolatban meg kell állapítanunk, hogy egy-egy elemének valóra váltása akár évtizedekig is eltarthat (mint például a Koppenhága tôszomszédságában kialakított, fejlett infrastruktúrával rendelkező Ørestad üzleti fejlesztési körzet létrehozása), míg másoké pusztán néhány hétig. Az egyes feladattípusok hagyományosan a várostervezô mérnökök, az ágazati tervezés és a múszaki igazgatás között oszlanak meg.

\section{Miként hozható létre a szervezeti architektúra?}

A várostervezéshez hasonlóan az IT eszközrendszer kiépítése is többlépcsős folyamat, amelyben keverednek a tervezés és a szervezeti architektúra-építés különböző fokozatai. A White Paper szóhasználatában a szervezeti architektúra (enterprise architecture) mindent felölelő kategória, ami a szakterület számos szintjére kiterjed: magába foglalja mind a stratégiaépítés, mind az implementáció ciklikus folyamatait, amelyeken keresztül az IT rendszer és annak használata módszeresen összhangba kerül az üzleti célokkal. ${ }^{2}$

Az architektúra-modell a szervezeti architektúra nemzetközileg elismert elveire épít. A modell megjeleníti azokat a folyamatokat, amelyeken az e-kormányzat kialakítása során a közszférának át kell mennie.

\footnotetext{
${ }^{2}$ A White Paper szövegében következetesen visszatérô terminus az „üzlet” (business). Ez a szóhasználat azt a törekvést kívánja erôsíteni, ami az üzleti élet eredményekre orientált szemléletét kívánja meghonosítani a közszférán belül. Üzleti célok alatt ebben az értelemben olyan tág célrendszert értünk, amely többek között magában foglalja a közszolgáltatások fogyasztóinak magas színvonalú kiszolgálást, valamint a szolgáltatások feltételeinek hosszú távú biztosítását.
} 
1. ábra

Az architektúra folyamatábrája

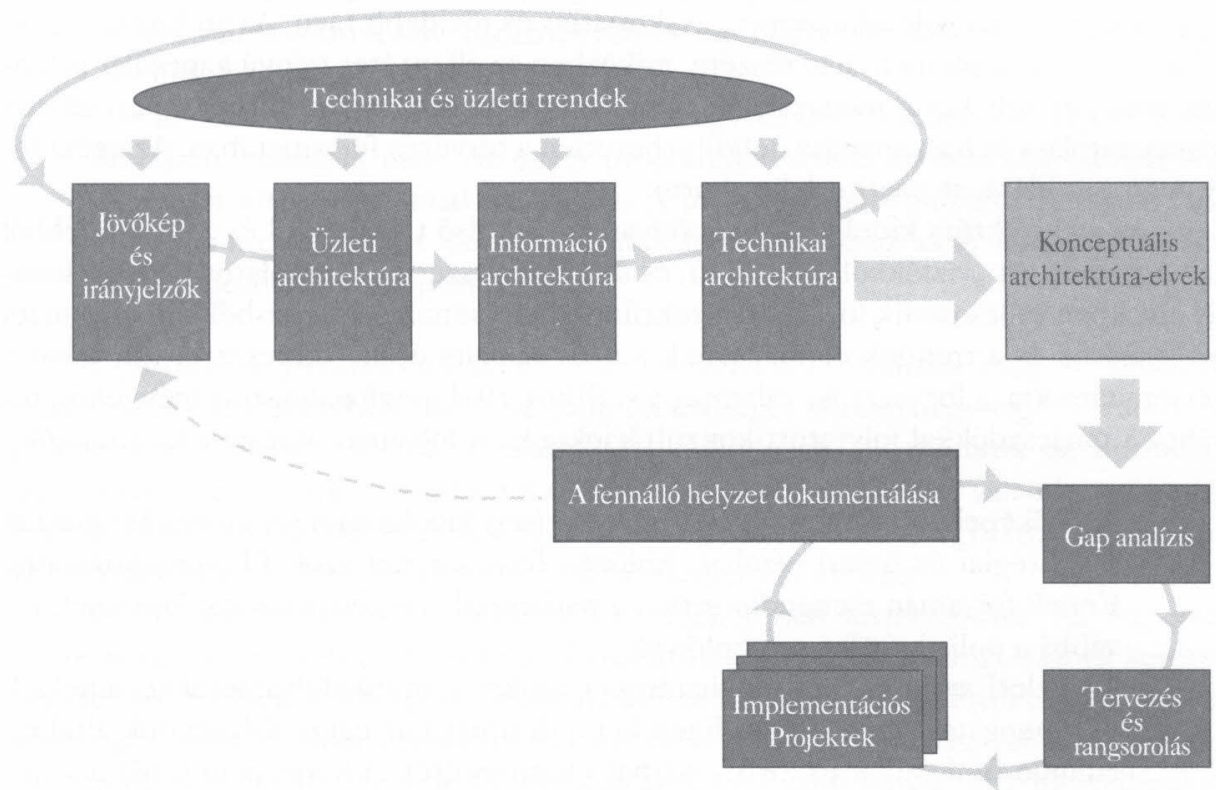

Az architektúra folyamatai túlmutatnak az IT keretein. Az optimális technikai architektúra kialakításának előfeltétele az üzleti jövőképek és célok pontos meghatározása, ezek szolgálnak azután használható alapul az IT rendszer fejlesztésének terveihez. Az architektúra folyamatai tehát az IT és az üzleti világ gyümölcsözô párbeszédén alapulnak.

Dániában az E-government Project a közszolgáltatások teljes rendszerét felölelô koncepció és különféle irányjelzők kidolgozásával készítette fel a közszférát a változásokra. A kidolgozott koncepció biztosítja új modellek kifejlesztését a közszolgáltatások átalakításhoz, hogy a mainál jobban és hatékonyabban szolgálják a felhasználók igényeit. Az E-government Project bizottság irodájaként múködő Digital Taskforce titkársága támogatja az egyes hivatalokat az átalakulás üzleti - vagyis a koncepcióra, a folyamatokra és az elérhetố eredményekre koncentráló, jellemzốen a menedzsment funkciójához tartozó - feladataiban, míg a Tudomány-, Technológia- és Újításügyi Minisztérium felel a technikai megoldásokért, például az információs és egyéb műszaki architektúrák kiépítéséért.

Az architektúra fejlesztése összetett folyamat. Magába foglalja a vízióalkotást és annak megvalósítását, majd múködtetését és értékelését is. Ugyanakkor a folyamat közel sem lineáris, tévedés lenne úgy felfogni, hogy egy $A$ pontból kiindulva $B$ pontba jut el. Az architektúra-építés folyamatos tevékenység, melynek az a célja, hogy biztosítsa az IT használati értékének folyamatos növelését. 
Az architektúra fejlesztése kölcsönhatásban áll az implementáció folyamatával. A két folyamat szorosan összekapcsolódik és együtt halad, ritmusuk azonban eltérô. Az architektúra-építés stratégiai jellegú, hosszú távú koncepcionális folyamat, míg az implementáció megoldásközpontú, gyakorlatias és rövidebb távú. Az architektúra célokat tûz ki az implementáció részére, miközben az ellentétes irányú kapcsolat is fontos szerepet tölt be: a megvalósítás során módszeresen összegyújtött tapasztalatok visszacsatolása és hasznosítása nélkülözhetetlen a tervezés folyamatában. Az egész folyamatot az alábbiak szerint lehet leírni:

Az architektúra kidolgozásának folyamata a külsố trendekből és a jövőképekből (az úgynevezett „víziókból”) indul ki, és az IT rendszerrel kapcsolatos koncepcionális elvekben csúcsosodik ki. Az architektúra kiépítésének sok lépésból álló folyamata az elvárások és a trendek elemzésének kettôs alapjára épül. Tekintettel van tehát a versenytársakra, a fogyasztók, valamint a szállítók által megfogalmazott igényekre, továbbá a tanácsadókkal folytatott konzultációkra is. A folyamat lépései a következók:

- A jövóképek és irányjelzók (direction markers) kidolgozása során meghatározzák a stratégiai és üzleti célokat, különös figyelemmel azok IT vonatkozásaira. Ennek folyamán elengedhetetlen a párbeszéd a vezetố szakmai körökkel, továbbá a politikai élet szereplőivel.

- Az üzleti architektúra meghatározza azokat a munkafolyamatokat, amelyek IT támogatást igényelnek. Ezen belül definiálja az egyes folyamatok által ellátandó funkciókat és azok elvárható környezetét. A koncepció tehát a munkafolyamatok elemzése és optimalizációja alapján jön létre.

- Az információs architektúra meghatározza a közös, koncepcionális megközelítésen alapuló üzleti stratégia információszervezési igényeit mind általános szinten, mind pedig az adatspecifikációk szintjén.

- A technikai architektúra meghatározása általános kategorizálási rendszer alapján történik. A technikai architektúra jelenti egyrészt a rendszer modulokra történő szétbontását, valamint az egyedi modulok funkcióinak egységes rendszerré szervezését. Kulcsfontosságú, hogy a kialakított architektúra a kívánt vagy éppen kikényszerített - üzleti változásokat szolgálja, amelyeket az IT rendszernek támogatnia kell.

- A koncepcionális architektúra-elvek a konkrét IT megoldások megválasztásának szabályai, amelyek biztosítják az összhangot a megfogalmazott igények és az információs struktúra, valamint a technikai architektúra között.

A stratégiai architektúra-építéssel párhuzamosan halad a gyakorlati, megoldásorientált, implementációs folyamat, ami az alábbi elemeket foglalja magába:

- A fennálló helyzet dokumentálása az operatív tevékenység részeként a jövőbe tekintố tervezés kiindulópontjául szolgál. A dokumentáció a jövôkép-alkotásnak, valamint az irányjelzốk kialakításának és rendszeres felülvizsgálatának is fontos eszköze.

- A hiányosságok elemzése (gap analysis) azt tárja fel, hogy a szervezeti felépítés, illetve az alkalmazott megoldások és módszerek mennyiben illeszkednek a kidolgozott koncepcionális architektúra-elvek rendszerébe. 
- A tervezés és a prioritások felállítása során alakítják ki azt a tervet, melynek alapján megtörténik a meglévő megoldások és a kidolgozott architektúra-elvek, illetve az üzleti célok között fennálló különbségek áthidalása. A tervezés fontos része az egyes részek rangsorolása. A prioritások felállításának alapja az egyes változtatások következményeinek számbavétele, különös tekintettel az általuk létrehozott üzleti értékre.

- Az implementációs projektek a terveket egyedi implementációs projektek keretében valósítják meg. Az egyes projektek - szoros koordináció mellett - a közösen kitűzött célokat szolgálják. A projektek portfolióként felfogott halmaza is menedzselést igényel, aminek fontos része az aktív kockázatkezelés és a teljesítmények optimalizálása.

A szervezeti architektúra fejlesztése irányelveket fogalmaz meg az általános adatszervezés tekintetében, továbbá több lehetőséget biztosít egy-egy IT rendszer funkcionális komponenseinek kiválasztására. Mindezek az előírások az optimális egyensúlyt igyekszenek biztosítani a célok és az üzleti elvárások, valamint az egyes rendszerek önálló múködése és két vagy több rendszer hatékony együttmúködése között; továbbá optimalizálják a rendszerek költséghatékonyságát.

Az IT beruházásoknak nyilvánvalóan értéket kell létrehozniuk. Az alaposan megtervezett szervezeti architektúra a beruházások precíz összehangolásának kereteit biztosítja, melyek segítségével kiaknázható az IT fejlesztések értéke. [...] A közszféra egészében alkalmazott szervezeti architektúra-keretrendszer, valamint a közös standardok biztosítják, hogy az IT beruházások ne házon belüli, zárt megoldásokat eredményezzenek, továbbá ezek segítik az újrahasznosítás filozófiájának átültetését a gyakorlatba. ${ }^{3}$

A szervezeti architektúra fontosságának hangsúlyozása mögött a közszolgáltatások összehangolásának és hatékonyságának megnövekedett igénye áll. Az e-kormányzati kezdeményezésekben testet öltő politikai akarat és a korszerú technológiában rejlô lehetôségek akkor válnak megvalósíthatóvá, ha a számos szereplố különbözô IT rendszereinek átjárhatósága (például XML), továbbá a közös standardok, szabályok és biztonsági követelmények (például elektronikus aláírás) bizonyos fokú összhangot teremtenek. Ennek támogatása lehetséges bizonyos szolgáltatások, például az adatok cseréjét és az elektronikus aláírásokat kezelő megoldások közös vezetés alatt történő bevezetésével.

A közszféra közös architektúrájának kialakítását a sæolgáltatásra orientált architektúra-modell teszi lehetôvé. Ebben az IT rendszerek átjárhatóságát a szolgáltatásokra kell alapozni, ami azt jelenti, hogy ha az egyik rendszerkomponens már kínál egy szolgáltatást, akkor egy másik ezt használja. Így a szolgáltatások összehangolt meghatározásával biztosítható az IT rendszerek közötti koherencia legjobb megoldása.

$$
[\ldots]
$$

\footnotetext{
${ }^{23}$ A szoftvereket úgy írják, hogy olyan funkcionális elemekből álljanak össze, amelyeket számos esetben újra fel lehet használni, mint az építőkockákat. - $A$ ford.
} 
Az alábbi táblázat a különbözô architektúra-modellek jellemzőit mutatja be:

1. táblázat

\section{A rendszer-architektúrák jellemző́i}

\begin{tabular}{|c|c|c|c|}
\hline & $\begin{array}{l}\text { Nagygépes (mainframe) } \\
\text { architektúra }\end{array}$ & $\begin{array}{l}\text { Kliens/szerver architek- } \\
\text { túra }\end{array}$ & $\begin{array}{l}\text { Szolgáltatásra orientált } \\
\text { architektúra }\end{array}$ \\
\hline Platform & $\begin{array}{l}\text { monolitikus és közpon- } \\
\text { tosított }\end{array}$ & homogén és ellenôrzött & $\begin{array}{l}\text { szétszórt és véletlensz- } \\
\text { erû }\end{array}$ \\
\hline Hálózat & zárt és korlátozott & $\begin{array}{l}\text { kiterjedt, de egymással } \\
\text { nem összekapcsolt helyi } \\
\text { hálózatok (LAN) }\end{array}$ & $\begin{array}{l}\text { internetalapú, mindenütt } \\
\text { jelenlévő, összekapcsolt }\end{array}$ \\
\hline Adatformátum & $\begin{array}{l}\text { nem transzparens, nem } \\
\text { hozzáférhetố }\end{array}$ & bináris, házon belüli & szemantikus, megosztott \\
\hline Technológiai fókusz & operációs rendszer & adatbázis & interfész \\
\hline Felhasználók & IT operátorok & ügyintéző dolgozók & $\begin{array}{l}\text { beszállítók, alkalmazot- } \\
\text { tak, ügyfelek/fel- } \\
\text { használók }\end{array}$ \\
\hline Üzleti érték & $\begin{array}{l}\text { adatközpontú, digital- } \\
\text { izált múködés }\end{array}$ & $\begin{array}{l}\text { adatszolgáltatás a fel- } \\
\text { használók részére }\end{array}$ & $\begin{array}{l}\text { üzleti agilitás, az alka- } \\
\text { Imazhatóság és interak- } \\
\text { ció támogatása }\end{array}$ \\
\hline
\end{tabular}

Forrás: The Stencil Group, www.stencilgroup.com

A szolgáltatásra orientált architektúra az egymással kommunikáló rendszerelemek ideális modellje, melynek egyik konkrét gyakorlati példája az Interneten keresztül igénybe vehetô szolgáltatások rendszere. Ez a modell ugyanakkor a közszféra számára is iránymutató lehet, akár az állampolgárok, a vállalatok vagy más hivatalok számára nyújtott, akár belsố szolgáltatásokról lett légyen is szó.

Ebben a kontextusban a szolgáltatások több szinten is értelmezhetők:

- Koncepcionálisan a szolgáltatásra orientált architektúra olyan modell, amelyben lazán összekapcsolt alkalmazások múködnek együtt, szolgáltatásaikat hozzáférhetővé téve egymás számára.

- Üzleti értelemben a szolgáltatások alatt adat- és funkcióalapú szolgáltatásokat értünk, amelyeket valaki - meghatározott üzleti feltételek mellett - hozzáférhetôvé tesz.

- Technikai értelemben a szolgáltatásra orientált architektúra bizonyos szabványok egy csoportját hasznosítja, amelyek folyamatos fejlesztés alatt állnak. Ezek határozzák meg a protokollokat, hogy ezáltal laza keretet biztosítanak az egyes rendszerek közötti programozott kommunikációhoz.

- Specifikusan a webes szolgáltatások olyan módszereket jelölnek, amelyek lehetôvé teszik valamely alkalmazás számára, hogy azt más alkalmazások megkeressék, és attól standardizált nyelven (XML) adatokat kérjenek le. 
2. ábra

Értékteremtố szervezeti architektúra

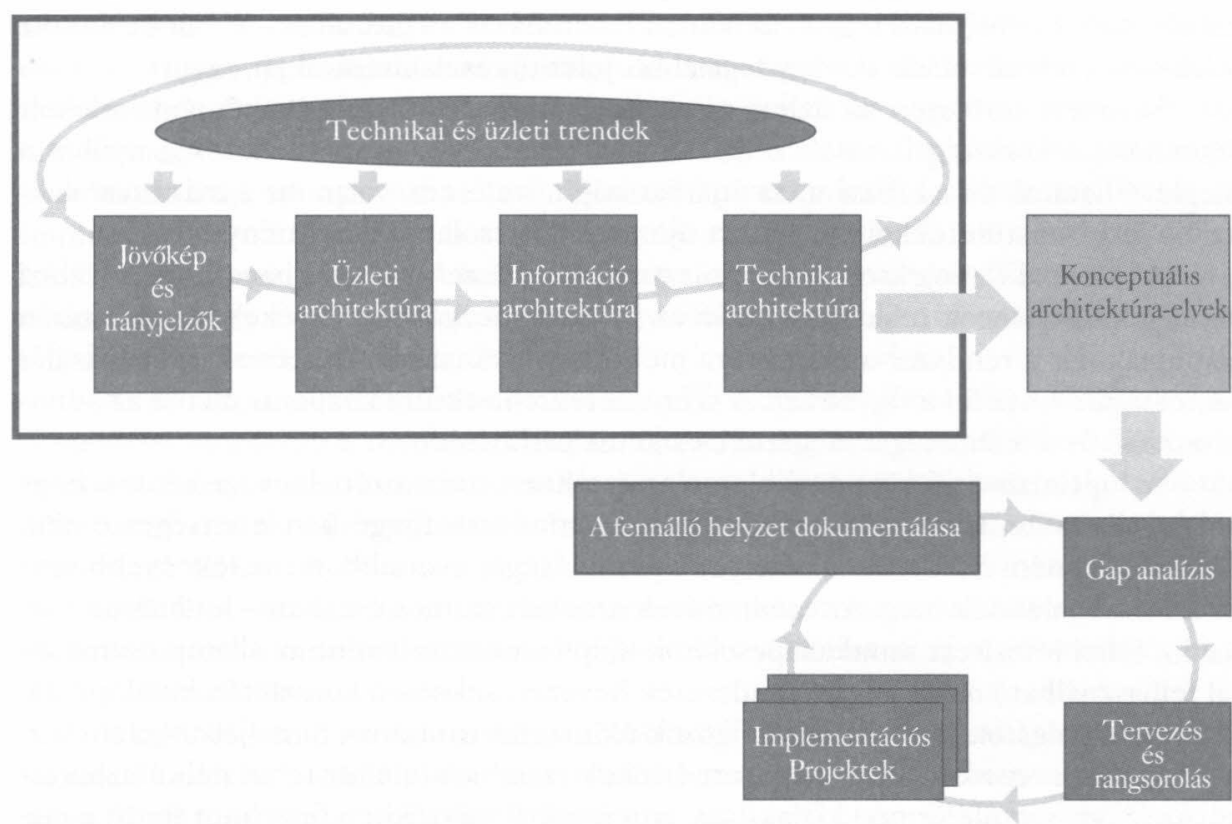

A szolgáltatásra orientált modell nem ír elő technológiai szabványokat, bár sok szállító konkrét technológiai platformot ajánl vele együtt. A szabványok közötti választás lehetôsége a koncepcionális architektúra-elvek megfogalmazásában fejezôdik ki, amelyek összefoglalják az építési folyamat közben előforduló döntési pontokat. A szolgáltatási interfészek szabványosítása rohamos tempóban zajlik számos nemzetközi testületben (W3C, OASIS, WS-I, stb.). Ez a fejlesztési folyamat a következô néhány éven belül várhatóan véget ér és kiforrott formában konszolidálja a technológiai szabványokat, melyek alkalmazása a következő évek építési munkájának központi feladata lesz a közszféra szervezeti architektúrájában.

A fenti ábrán a felsố keret jelzi az architektúra stratégiai fontosságú folyamatait. A szervezeti architektúra megszervezi az IT rendszerek tervezésének folyamatát, és ezen keresztül biztosítja az IT beruházások üzleti értelemben vett értékét. Az építési folyamat kiindulópontja ennek megfelelően a „közszolgáltatások üzleti szükségleteinek" megfogalmazása, amelyek azután átfordítandóak az IT szükségletekre. Ilyen összefüggésben tehát a technológiai paraméterek és az IT piac egyes termékei mint az IT támogatás megvalósításának legcélravezetốbb eszközei fontos, de csak másodlagos szerepet játszanak.

A közszféra meglévő adminisztratív folyamatai nem szolgálhatnak kiindulópontul a fejlesztés alatt álló rendszer IT igényeinek meghatározásánál. A meglévő munkafolyamatok egyszerű IT támogatása nem képes a valódi előnyök kiaknázására, abból az egyszerủ okból kifolyólag, hogy ezek a folyamatok olyan korlátok között alakul- 
tak ki, amelyeket az IT nem képes megoldani. Az információs technológia tehát a folyamatok optimalizálásának új lehetőségét biztosítja, amellyel nagyobb hatékonyság és magasabb szintû szolgáltatási minôség érhetố el. Ez számos esetben - annak érdekében, hogy biztosítható legyen az adott IT beruházás megtérülése - a már bejáratott folyamatok felszámolásával, vagy legalábbis jelentős átalakításával jár együtt.

Valamely területen az üzleti célok meghatározásakor mindenképpen indokolt átgondolni a közszolgáltatások céljait és jövőképét. Így ugyanis lehetôség nyílhat a meglévő határok újraszabására, az átjárhatóság növelésére, valamint a más hivatalokkal és magántestületekkel kialakított új munkakapcsolatok intézményesítésére.

A sikeres IT projektek az adminisztrációs rendszerek alapos ismeretén, továbbá a szolgáltatási láncok teljes hosszában az IT által mozgósított értékek hasznosításán alapulnak. Ez a rendszer-architektúra mellett a folyamatelemzés és az optimalizálás fontosságára hívja fel a figyelmet. A szervezeti architektúra központi eleme az adminisztráció és a technológia megértő és sikeres párbeszéde.

Az optimalizáció központi eleme az értékteremtés, ezért lényegi kérdés, hogy hol és milyen formában keletkezhet érték. Számos összefüggésben lehetségessé válik a belső eredmények feltárása, amelyek a jó minőségű, gyorsabb, termelékenyebb ügyintézésben jelennek meg. Az eredmények azonban számos esetben - különösen harmadik féllel létesített munkakapcsolatok kiépítésekor, valamint az állampolgárok által felhasználható önkiszolgáló rendszerek bevezetésekor - a közszférán kívül, például az állampolgárok és a vállalati dolgozók időmegtakarításának formájában jelentkeznek. Az IT bevezetése által teremtett értékek számbavételéhez tehát nélkülözhetetlen az átfogó szemléletmód kialakítása, ami ésszerū mértékben figyelmet fordít a másodlagos, illetve a külső hatásokra, az úgynevezett externáliákra is.

A szervezetépítés nélkülözhetetlen velejárója a folyamatos párbeszéd a közszolgáltatások menedzsmentjével, ami ebben az összefüggésben a szponzor szerepét játssza. Eközben az építész feladata egy olyan IT stratégia felvázolása, amelyben a döntési helyzetek üzleti alternatívákként jelennek meg, vagyis annak érdekében, hogy a döntések megbízható alapra támaszkodva szülessenek meg, szükség van mind az elốnyök, mind a hátrányok kielégítő leírására.

Ilyen döntési alap megteremtéséhez elengedhetetlen az egyes IT megoldások komponenseinek alapos ismerete, különös tekintettel az implementációban betöltött szerepükre. Csak ez eredményezheti a költségek és a használati érték reális számbavételét. Ezért a szervezeti architektúra-építés fontos eszközeként szisztematikusan fel kell használni az összehasonlítható helyzetek és IT megoldások tapasztalatain alapuló benchmarking modelleket.

Az architektúra-építés különbözô lépcsőfokain meghozott döntések az optimalizáció részét képezik. Az információs architektúra kiválasztásának például a felhasználók információs igényeinek kell megfelelnie. Amennyiben a közös adatokhoz történő párhuzamos hozzáférés igénye több földrajzilag elkülönülố irodában lép fel, optimális lehet az adatok központosítása, míg azokban az esetekben, amikor az információ felhasználása elsősorban helyben történik, elosztott információs architektúra kiépítése lehet indokolt. Ennek a megfontolásakor természetesen figyelembe kell venni a hozzáférhetố kommunikációs eszközök költségeit (az árak mellett a minőség tekintetében is), amelyekkel a központosított adatkezelés széleskörúen jelentkező pozitív hatásai állíthatóak szembe.

A szervezeti architektúra értékalapú célok szerint történő optimalizálásakor az 
IT megoldás teljes életciklusán keresztül kell figyelembe venni a döntések várható következményeit. Az architektúra kidolgozása közben gyakoriak az olyan döntések, amelyek messzemenő következményekkel járnak. Ilyen például az interfészek és adatszerkezetek kiválasztása. Ezekben az esetekben számos késôbbi modernizációs döntést, vagy éppen az adott megoldás más rendszerekkel történô összekapcsolásának kérdését évekkel késôbb is befolyásolhatja - pozitívan vagy negatívan - egy korábban meghozott döntés. Az architektúra kidolgozásának ezért a közszféra szervezeti architektúrájának optimalizálását elôíró irányelveken kell alapulnia, amelyeket az implementációs folyamatok hosszú távon követnek. Ezeknek az irányelveknek mind helyben, mind pedig a közszféra egy-egy szegmentumát átfogóan - azt kell biztosítaniuk, hogy a szükséges integráció egy idôben valósuljon meg az IT megoldás használati értékének optimalizálásával.

A szervezeti architektúra nemcsak az új IT megoldások esetében létfontosságú. A meglévố megoldások modernizálásakor, új technológiával történố kibôvítésekor az interfészekkel és adatformátumokkal kapcsolatos döntések meghozatalakor szintén előmozdíthatja az ITT megoldások funkcionális integrációjának megteremtését. A rendszerek közötti koherencia megteremtésének, valamint a különböző rendszerek kombinált életciklusára kivetített költséghatékonyság maximalizálásának elengedhetetlen feltétele a meglévő rendszerek fejlesztése, valamint az új rendszerek létrehozásának összehangolt tervezése.

E tekintetben fontos, hogy olyan „többszálú” megoldásokat válasszunk, amelyek képesek kielégíteni a különböző szervezetek igényeit, miközben biztosítják a szervezetek közötti funkcionális együttmúködést is. Célszerủ olyan általános irányelvek kialakítása, amelyek alapján felmérhetôvé válnak a közszféra különbözô IT rendszereinek integrációs igényei és az integrációval elérhető értéktöbblet is. Ezek az elemzések azoknak a stratégiai forgatókönyveknek a kidolgozásához nyújtanak segítséget, amelyek a meglévő, de elavult rendszerek további fejlesztéseit határozzák meg.

\section{$[\ldots]$}

\section{Gazdasági perspektívák}

A közös architektúrát alkalmazó szervezetek tapasztalatai azt mutatják, hogy a szervezeti architektúra fokozott figyelembevétele helyes befektetés. Az architektúra kérdése lényegében mindig is mérlegelés tárgya volt. Amikor a közszféra követelményeket állít fel az architektúrával szemben, az architektúrára vonatkozó döntéseket - alaposabb gazdasági megfontolások alapján - a rendszerek tulajdonosai és felhasználói hozzák meg. Végeredményben tehát olyan döntések születnek, amelyek eredményeként az IT költségvetésben és az üzleti folyamatokban egyaránt komoly nettó nyereség érhetố el.

A megtakarítások kiszámításánál az architektúrához szervesen nem kötődő karbantartási és adaptációs költségeket is figyelembe kell venni. A hozamok számításának alapja a bevezetett rendszer teljes élettartamára vetített megtakarítás. Más szavakkal tehát a számítások alapját a beruházás hozama (Return on Investment, ROI) és a rendszer birtoklásának teljes költsége (Total Cost of Ownership, TCO) képezi.

A számvitel valamennyi jövedelmet és megtakarítást, továbbá minden beruházási és üzembenntartási költséget nyilvántart, az ismeretek megszerzésétől kezdve 
egészen az IT rendszereket üzemeltetô szakemberek és a felhasználók képzéséig.

A megfelelô szervezeti architektúra kialakításának eredményei messze túlmutatnak az egyes megoldások által felmutatható megtakarításokon. Az IT megoldások gyakorlati értékének realizálásához, vagyis például a magasabb termelékenység, a jobb minôség és a felhasználói elégedettség eléréséhez elengedhetetlen a jól kiépített architektúra. Általa egyszerủbbé válik új szervezeti egységek, új szolgáltatások és munkafolyamatok gyors implementációja. Mindezek a hozamok objektív mérési módszerek hiányában nehezen számszerúsíthetôk, ezért indokolt a megtérülési kimutatás (business case) elkészítése, valamint az eredmények nyilvánosságra hozatala.

A szervezeti architektúra optimalizálásának általános célja - az IT megoldások költségeinek leszorítása mellett - az eredményesség növelése. Mivel az átalakítások által generált hozamok gyakran a beruházás helyétôl távol jelentkeznek, ezek a döntések gyakran csak nehézségek árán igazolhatóak. Általánosságban elmondható, hogy a gondosan kialakított architektúra javarészt múködés közben mutat fel eredményeket, tehát a beruházás gazdaságossági szempontból csak évekkel a döntéseket követően igazolható a költségvetésben.

A nyereségesség csak átfogó szemlélettel értékelhető:

- Először is, az IT beruházásokat intézmények csoportos befektetéseként vagy több szektort érintô közös beruházásként kell kezelni. Ebból kifolyólag különös figyelmet kell szentelni a költségek és a hozamok megosztására, aminek egyik bevált technikája a megosztási kulcsok alkalmazása a beruházásban.

- Másrészt szükséges lehet a jelentkező költségek és hasznok összekapcsolása a beruházások kezdetétôl fogva, az IT megoldás teljes élettartamán keresztül. Ez olyan pénzügyi modell alkalmazását teszi szükségessé, amely elôkészíti a talajt az architektúrára vonatkozó döntéseknek a megoldás általános gazdaságosságának figyelembevételével történő optimalizálásához. Erre alkalmas lehet például az a módszer, amikor az egyszeri központi beruházás finanszírozásának költségeit a felhasználók havi díjakon keresztül fizetik meg.

- Harmadszor, szükséges lehet az egyedi igényekre szabott megoldások és a szóba jöhető üzemkész megoldások közötti egyensúly megteremtése. Ennek keretében érdemes figyelmet fordítani az újrahasznosítás, illetve az egymással összekapcsolt megoldások lehetôségeire. Bár egy-egy adott IT szükséglet egyszerű megoldásokkal könnyen kielégíthető, érdemes végiggondolni más szereplôkkel közös megoldások lehetséges hozamait is. Ez még akkor is igaz lehet, ha az utóbbi megoldás sokszorosan összetett. [...]

Összefoglalásul, megfelelố kontrollmechanizmusok kialakítása szükséges ahhoz, hogy az architektúrát érintő döntéseket valamennyi érintett fél érdekeinek figyelembevételével és az optimális gazdaságosságra való tekintettel hozzák meg. Ehhez hozzátartozik bizonyos szervezési és vezetési elvek, ösztönzôk vagy megállapodások alkalmazása a menedzsment részéről. Az alábbi gazdasági modellek jól példázzák az ilyen kontroll-mechanizmusok múködését: 
- Központi beruházás közös infrastruktúra létrehozására, a költségek megosztásával a felhasználók között a tényleges használat vagy eszmei hányadok arányában.

- Használati jog biztosítása harmadik fél számára, költségalapú árazás mellett.

- Koncessziók értékesítése közszolgáltatást végzô vagy infrastruktúrát biztosító beszállítók részére, kereskedelmi alapon.

- A közszolgáltatásokhoz kapcsolódó vagy közös specifikációjú feladat- és adatszerkezeteket alkalmazó IT projektek állami támogatása.

A gazdasági modelleknek az IT beruházások optimalizálását kell támogatniuk. Segíteniük kell továbbá a szervezeti architektúra-építés elveinek, valamint az ezek segítségével elért eredményeknek a megismerését, elterjedését és elfogadását. Ez a helyi beruházások során az eszközök közös használatából fakadó nyereségeket, megtakarításokat fog eredményezni, rövidebb gyakorlati megvalósítást, mivel azok alkalmazása az egyedi megoldásoknál olcsóbbá válik. Ez tágítja a végfelhasználók mozgásterét az eredményességet és a hatékonyságot növelő IT megoldások kiválasztása terén.

Forditotta: Gaugecz Ádám, Rohonyi András 